\title{
Perlite Resources of
}

\section{the United States}

By MARION C. JASTER

A CONTRIBUTION TO ECONOMIC GEOLOGY

I GE OLOGICALS SRVEY B ULLETIN 1027 - I $1+4$

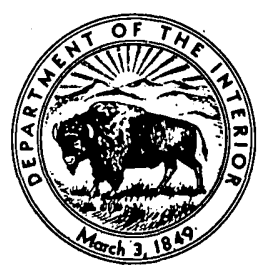


UNITED STATES DEPARTMENT OF THE INTERIOR

Douglas McKay, Secretary

GEOLOGICAL SURVEY

W. E. Wrather, Director

For sale by the Superintendent of Documents, U. S. Government Printing Office Washington 25, D. C. 


\section{CONTENTS}

$\rightarrow \quad$
Abstract .

\section{ILLUSTRATION}

Plate 44. Index map of perlite resources of the United States, including processing plants

In pocket

\section{TABLE}

Table 1. Published chemical analyses of the 6 common volcanic glasses 


\title{
A CONTRIBUTION TO ECONOMIC GEOLOGY
}

\section{PERLITE RESOURCES OF THE UNITED STATES}

\author{
By Marion C. Jaster
}

\begin{abstract}
This report abstracts the published information on geologic occurrence and distribution of perlite in the United States. Perlite is important in the growing light-weight aggregates industry. The geology and petrology of perlite are described and brief mention is made of mining, milling, processing, economic factors, and reserve figures where known. A table of analyses of the rhyolitic, latitic, and dacitic perlite, welded tuff, pitchstone, and obsidian is included mainly to show the water content. The index map shows known deposits and the geology of areas in which possible deposits may be found. The locations of processing plants are indicated to show their economic relationship to the deposits and to markets.
\end{abstract}

\section{INTRODUCTION AND HISTORY}

The marked growth of the light-weight aggregates industry and the introduction of naturally occurring materials not heretofore used in light-weight construction have caused a demand for basic knowledge of these materials.

The purpose of this report is to give the location of perlite deposits which are now being mined and of many which may achieve economic importance, and to provide brief notes concerning these deposits. The occurrence of perlite as well as some features of mining, processing, and utilization are briefly stated.

Many geology students have noted that some volcanic glass when inserted in a bunsen flame, will froth or intumesce, but only recently has this property been utilized commercially. Obsidian was reported to have been expanded and used in abrasive bricks in Germany in 1924. Perlite is reported to have been treated in a kiln at Las Vegas, Nev., in 1940 and the product mixed with gypsum for plaster. About 1941, Lee Boyer, an assayer of Superior, Ariz., while experimenting with perlite for use as an enamel, built an experimental gas-fired furnace in which the perlite was flash-popped. The product was placed in a classifier in which the heavy impurities dropped to the bottom, and the white, frothy product was recovered. Soon many small plants were built so that experiments could be made in the treatment and uses of perlite. Some of the products were of indif- 
ferentvalue and were rejected by the building trades. Later the Perlite Institute was organized to set commercial standards, and the industry achieved a firm competitive footing.

\section{SOURCE OF DATA AND ACKNOWLEDGMENTS}

This compilation was prepared entirely from available published reports; geologic maps were the chief source of information on the geologic distribution of the perlite deposits.

The writer is indebted to Eugene Callaghan, director of New Mexico Bureau of Mines and Mineral Resources, for his suggestions and for furnishing information on the geology and petrology of perlite and information on the New Mexico deposits. Special thanks are also due Aaron C. Waters, department of geology, Johns Hopkins University, for his suggestions and criticism and for information on the Washington and Oregon deposits.

\section{PETROLOGY AND GEOLOGY}

In commercial usage the term "perlite" refers to any naturally occurring glass of igneous origin that will expand when either slowly or quickly heated to yield a frothy, light product. The term is also applied to the expanded product. In strict petrological usage the term "perlite" is restricted to a single variety of volcanic glass in which strain incident to cooling has yielded a concentric or "onion" structure of fracturing which may be visible to the naked eye or may be observed only under the microscope.

The volcanic glasses that froth to a product of commercial grade on heating generally have a chemical composition corresponding to that of rhyolite when computed on a water-free basis, although some are dacite. Table 1 gives the chemical analyses of the common volcanic glasses. The silica content is normally greater than 70 percent. The water content may range from less than 1 percent in some obsidian to as much as 10 percent in some pitchstone. Most of the volcanic glass used commercially has a water content ranging from 3 to 5 percent. Volcanic glass having the chemical compositions of latite, andesite; or basalt are not used. According to a report by Goranson (1931), it was demonstrated in the laboratory that a glass of the composition of granite or rhyolite can retain as much as 10 percent water, depending on the confining pressure. There is some controversy as to whether the water is in a molecular state or is dissociated. Thermal curves show that upon heating, the water is released at a regular rate so that partial crystallization is not $\varphi$ a necessary state of the glass in so far as the water is concerned. 


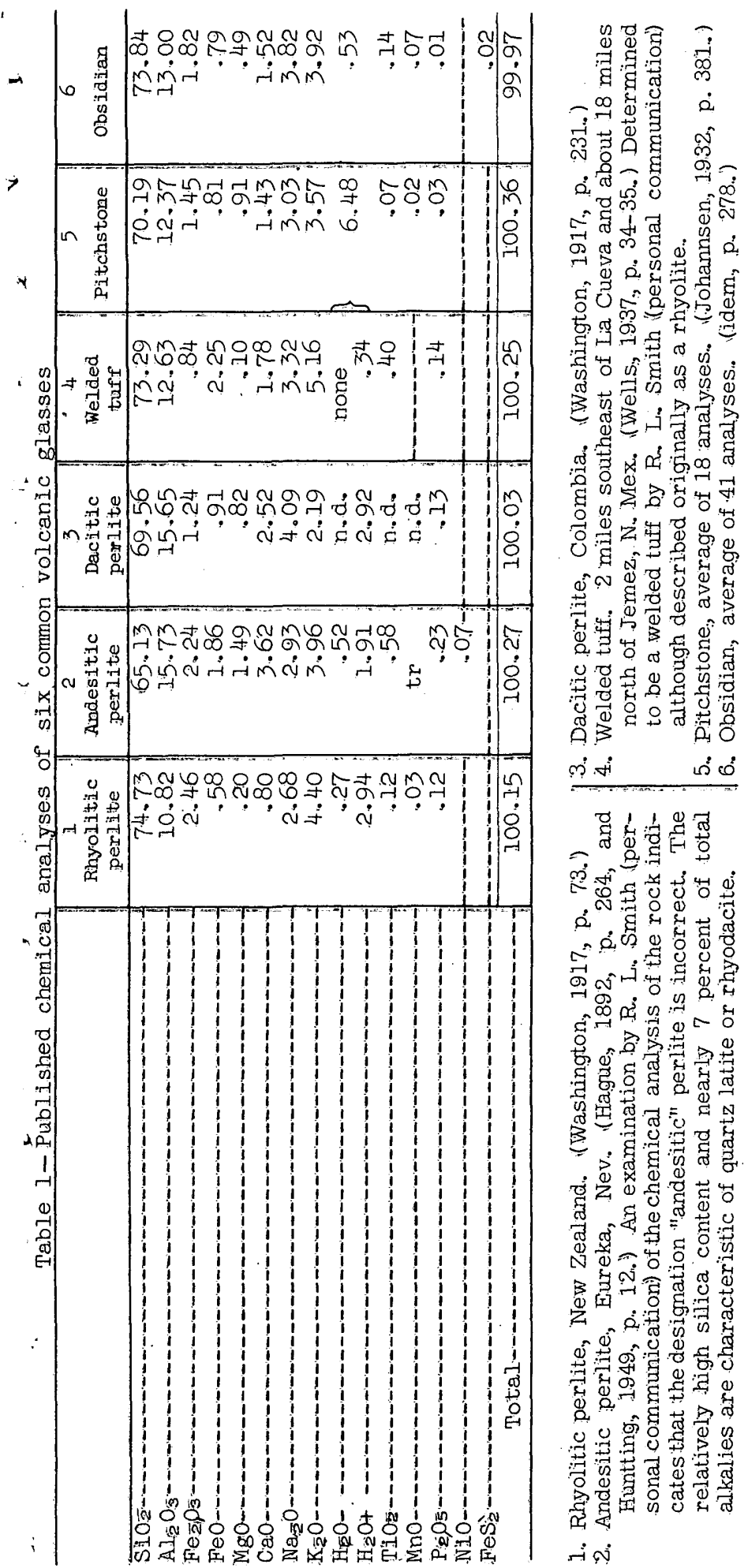


Petrographically, glass may be essentially free of crystalline material but most glass contains microscopic crystallites and also large crystals or phenocrysts which may range in proportion from a percent or so to as much as 50 percent or more in rocks known as vitrophyres. Spherulites are common and may make up most of the rock. With increasing crystallization, the glass becomes crowded with minute grains, grading into stony rhyolite. This crystallization may take place throughout a mass or in alternate bands of almost microscopic proportions, and is probably more closely related to original variations in water content than ${ }^{4}$ to rate of cooling. Glass may also be devitrified by the effects of steam from fumaroles or hot springs. Volcanic glass also devitrifies in time under the normal conditions of burial. Hence. very few occurrences of undivitrified glass older than Cretaceous are known. Under certain conditions of devitrification, glass may yield an aggregate in which a montmorillonite type of clay is the end product. Silicification or opalization of glass may also take place by processes operating subsequent to the emplacement of the body of glass. Recognition of the crystals and devitrification products is critical in evaluation of a perlite deposit, as the presence of any of these materials beyond certain low limits will make a deposit commercially unusable.

The glass itself may show a variety of characteristics depending in part upon its water content and its eruption history. It may range through all shades from black to nearly white. It may be red, green, or brown but very rarely blue. Some dense varieties, such as obsidian, break with conchoidal fracture. Certain varieties have closely spaced concentric fracture patterns or "onion" structure, the true perlite of the petrographer. Some glass has a columnar or prismatic jointing that may yield needles of glass on disintegration. Other varieties contain vesicles and show strong flow structure, the "pumiceous perlite" of the commercial operator. Pumice, which commonly occurs as discrete fragments, is a variety of glass, and most pumice will expand when subjected to heat treatment. The fine fragments of glass:in volcanic ash will also generally expand. Fragments "welded, " or partly melted together by natural processes to make a solid glass known as welded tuff or ignimbrite, likewise may be expanded. Many large deposits of perlite and pitchstone are intrusive, occurring as dikes, sills, and particularly as a quickly cooled selvage on the margin of volcanic necks or other intrusive bodies.

Solid glass or perlite has a hardness between 5.5 and 7. The specific gravity ranges between 2.2 and 2.4 and the weight from 139 to 150 pounds per cubic foot.

Volcanic glass is a product of igneous processes within the crust of the earth and with possible rare exceptions is not a product of any environmental effect subsequent to eruption. Volcanic glass which is erupted violently through the agency of contained 
gasses as clouds of particles may accumulate on the earth's surface as pumice and ash. Glass which is broken into particles by less violent evolution of gas, and which flows from craters or fumaroles will, if retaining sufficient heat and fluxing agents, yield a compact glass or welded tuff. Still less violent or slow eruptions of nearly congealed glass will, on reaching the orifice, expand into a dome. If more material is erupted than can be contained in a dome, the glass will spread over the surface as a flow. Owing to its viscosity at the time of eruption, glass may contain flow structures of considerable variety and arrangement. Gas trapped as bubbles may be retained sufficiently long to induce crystallization and devitrification in the immediate vicinity, yielding structures known as lithophysae. Other structures have been discussed previously. Because of the delicate balance between the glassy and crystalline states, part of a mass of glass may change to lithoidal rhyolite. This may take place either after flowage has ceased or justas the mass comes to rest. Single masses have been observed to change along the flow banding from solid glass through a zone of intricately interlayered glass and rhyolite to rhyolite without appreciable glass. The reasons for the change from glass to lithoidal rhyolite are not clearly understood but are probably related to segregation of volatiles into layers during flowage. As most of the water present in the glass is absent in the lithoidal material, the chief cause of crystallization and devitrification is probably in the mechanism for release of water during cooling.

As undevitrified siliceous volcanic rocks are limited to the western part of the United States, all deposits of perlite occur there. Volcanic ash deposits reach into the Great Plains States. Although rare occurrences of volcanic glass are known in volcanic sequences as old as Cretaceous, most glass occurs in sequences "of Tertiary or Quaternary age. Rocks of similar nature in the older systems are thoroughly devitrified. Mono Craters, Calif. , and probably many other occurrences are younger than the last glaciation in the area and some are post-Columbian. Perlite, pumice, and volcanic ash in Oregon occur in rocks ranging in age from Eocene to post-glacial. The perlite deposits that have been wo rked commercially are of Eocene and Oligocene age. Commercial pumice and ash deposits of Oregon are chiefly Pleistocene and post-glacial.

\section{ANNOTATED LIST OF PERLITE OCCURRENCES IN THE WESTERN UNITED STATES}

In this section the term "perlite" is used in the commercial. sense. All types of occurrences are reported here, with such 
brief information as could be gleaned from many sources. The geology of very few deposits has been studied: adequately.

Depositśs aré listed allphabetically by States, and by counties within the States. The numbers after the name of the deposit correspond to the numbered location on the map (p1. 44).

\author{
A:RIZONA \\ Gilia: County: \\ Deposits north of Winkleman (11). (Wilson and Roseveare, 1945, p. 5.) \\ Greenlee Cournty: \\ Undeveloped gray to black perlite, associated with agglomerate. (Wood; ; \\ 1948 , p. 11.)

\section{Maricopa County:} \\ Deposit of dark=grày perlite near Aquila. (Wood, 1948; p. 11.) \\ Deposits in the western part of the county. (Wilson and Roseveare, 1945, \\ p. 5.) \\ The following information on Mohave, Pinal, and Yuma Counties was taken \\ from Wilson and Roseveare (1945, p. 5-8).
}

\title{
Mohave County:
}

Perlite deposits north of Haviland (4) and southwest of Yucca (3) are less than 2 miles from the Santa: Fe railway. They are in secs. 22, 26, 27, 28, 34, and $35, \mathrm{~T} .17 \mathrm{~N}$; , R: $18 \mathrm{~W}$. ; in the Black Mountains.

Perlite occurs in the east=central: part of the Black Mountains, in T. 22 and $23 \mathrm{~N}$. , R. 19 and $20 \mathrm{~W}$. (1). It occurs along the ridges for 3 miles south of the Producers mine.

In sec. $2, \dot{T} .22 \mathrm{~N}$;,$R_{i} .20 \mathrm{~W} .(2)$, a mass of perlite about 25 feet thick and dipping $30^{\circ}$ west rests upon thick volcanic breccia and is overlain by tuff. This outcrop extends southward for about one-quarter mile:

The Black Mountains attain an al titude of 5,500 feet. The southern and central parts of the range are mostiy Tertiary volcanic rocks, which are 8,000 to 10,000 feet thick and consist chiefly of trachyte, andesite; latite, tuff, and, basalt. In the uppere part of this volcanic series; the perlite ranges in thickness from 25 to 100 feet.

\section{Pingl County!}

West of the Superior mining district, large deposits of perlite are common within a northwestatrending area about 10 miles long and $2 \frac{1}{2}$ miles wide. These deposits $(7,8,9)$ are from 3 to 7 miles from Superior; which is near the Magma Arizona Railroad; U. S. Highway 60, and the Ray highway.

The perlite of the Superior area rests upon tuff or breccia and is underlain by glassy rhyolite. Some of the occurrences are as much as a few hundred feet in width but vary greatly in areal extent.

Yum County:

A deposit (5) in the Chocolate Mountains.

CALIFORNIA

The information on Inyo County was obtained from Norman and Stewart (1951, p. 104-106);

\section{Inyo Countyi:}

The Coso deposit (24), T. 21 and 22 S., R. 38 E., Mount Diablo base line and meridian; is about 7 miles northeast of Coso Junction and 2 miles west of Coso Hot Springs. The perlite deposits are domes associated with pumice.; 
These domes are conical masses which rise to an average height of 300 feet above granitic hills. The perlite in places is pumiceous, light gray and green, and shows well-developed flow banding. Black obsidian is associated with the perlite, which in some places grades into a mixture with pumiceous obsidian.

The Fish Springs deposit (19), secs, 19 and 30, T. 10 S., R. 34 E., Mount Diablo base line and meridian, is 7 miles south of Big Pine and 3 miles west of * Fish Springs. The deposit is at the eastern end of a hill near the base of the Sierra Nevada. The hill is composed mainly of glassy volcanic rocks. The pumiceous perlite at the top grades downward into a rather flat-lying zone of a more pumiceous perlite which is about 40 feet thick. Beneath this pumiceous $\rightarrow$ perlite is a brecciated obsidian underlain by a glassy perlitic vitrophyre.

The Brooke deposit (20), secs. 24 and 25, T. 10 . S., R. 33 E., and secs. 29 and 30, T. 10 S., R. $34 \mathrm{E}$., Mount Diablo base line and meridian, is 7 miles south of Big Pine and $3 \frac{1}{2}$ miles west of Fish Springs. The geology and varieties of perlite as a whole on the Brooke property are the same as those in the Fish Springs deposit.

The Sheephead Mountain deposit (26) is in the western part of T. 21 N., R. $5 E$., San Bernardino base line and meridian, about 8 miles southwest of Shoshone. A series of lava flows and tuffs that dip steeply toward the east and strike about $\mathrm{N} .15^{\circ} \mathrm{E}$. make up the east side of Sheephead Mountain. The best grade of perlite is found at the base of the mountain in a flow 25 to 40 feet thick. Opalized tuff occurs between two perlite flows, In the lower perlite small fractures are filled with opalized tuff.

The Shoshone deposit (27) is in secs, 26 and 35, T. 22 N, , R, 6 E, , San Bernardino base line and meridian, on the east side of Dublin Hills about 2 miles west of Shoshone. The Dublin Hills consișt of lava flows, tuffs, and breccias that are above Paleozoic sedimentary rocks. The perlite occurs in lenticular flows and irregular bodies overlying tuffs and breccias, and is below and grades into spherulitic and vesicular rhyolite. The upper part of the perlite flow contains many lithophysae partly filled with quartz, chalcedony, and calcite. The perlite is greenish gray and contains scattered crystals of quartz, orthoclase; and biotite. The perlite at the bottom of the flow is pumiceous and brecciated in places, and the tuff under the perlite is changed to opalite,

The Southern Death Valley deposit (25) is about 22 miles south of Furnace Creek Inn, and 4 miles southwest of Bennetts Well, Death Valley National Monument. The perlite flow varies in thickness and dips steeply toward Death Valley. It rests upon a flow of porphyritic rhyolite and is overlain by rhyolitic tuffs and agglomerates. The perlite is light gray and ranges from soft and pumiceous to dense and glassy material. The perlite shows a well-developed perlitic structure.

The Staats deposit (23), in the southern part of T. 18 S., R. 38 E., Mount Diablo base line and meridian, is about 13 miles south of Keeler, and at the northern end of Coso Range. The perlite is a plug-dome intruded into flatlying tuffs, agglomerates, and andesitic flows, Light-gray perlite around the outside rim of the dome contains many fragments of black obsidian where it is in contact with the tuffs and agglomerates. The perlite deposit is about 10 feet thick and is very pumiceous at the center of the dome.

Other occurrences of perlite in Inyo County are reported at Salisbury Páss about 12 miles west of Shoshone, and in Grapevine Canyon,

\section{Kern County:}

The following information on Kern County was obtained from Tucker, Sampson, and Oakeshott (1949, p. 249), with the exception of the Black and Grey Eagle deposits.

Perlite (31) crops out in many places in sec. 22, T. 31 S., R, 34 E., Mount Diablo base line and meridian. Dark-gray perlite (Miocene) occurs as irregular flows associated with perlite breccia, rhyolite flows, tuffs, domes of dacite, and lake beds.

Black Eagle (29) and Grey Eagle deposits (28) consist of two 160-acre placer claims in the El Paso Mountains on the ridge north of Last Chance Canyon, in 
sec. 4, T. 29 S., R. 38 E., and sec. 32 , T. 28 S., R. 38 E., Mount Diablo base line and meridian, $7 \frac{1}{2}$ miles north of Saltdale. (Tucker, Sampson, and Oakeshott, 1949, p. 249 and Chesterman, 1950, p. 200.) The perlite occurs in flows of rhyolite that in places rest upon large flows of basalt. Locally, tuffs and lake (lower Pliocene) sediments rest upon the perlite. Perlite is exposed in many places on the Grey Eagle claim. In the southern half, it is 200 feet wide. In places the perlite and volcanic ash are overlain by basalt. Two deposits are on the Black Eagle claim. An exposure 1,000 feet long, 600 feet wide, and 30 feet thick is on the south end of the claim.

Other deposits (30) in Kern County are 8 miles north of Cantil in the El Paso Mountains and in sec. 27, T. 30 S., R. 36 E., Mount Diablo base line and $\alpha$ meridian. (Calif. Div. Mines Min. Inf. Ser. 1948, p. 1, and Min. World, 1948, v. 10 , no. 7, p. 64.$)$

\section{Lake County:}

Southwest and east of Clear Lake dacite is overlain by a large flow of pumiceous obsidian. Parts of this obsidian have expanded to a light white fluffy material. (Chesterman, 1950, p. 200.)

\section{Lassen County:}

Deposits of gray perlite (5) on the west flank of Hot Springs Peak, 4 miles northeast of Wendel, are associated with andesitic agglomerates and dikes of rhyolite. (Chesterman, 1950, p. 200.)

\section{Modoc County:}

Perlite deposits are in the northern part of Warner Range near Sugar Hill and Fandango Peak $(1,2)$. On Sugar Hill, light-gray perlite flows occur with lithoidal rhyolite and olivine basalt. Near the top of the flow, thin lenticular bodies of fractured grayish obsidian are in soft, friable perlite. On the west side of Fandango Peak, a perlite flow is overlain by basalt and underlain by rhyolite. The flow is about 100 feet thick, but 2 miles south of the peak the flow thins out and becomes more pumiceous. (Chesterman, 1950, p. 200.)

The Evening Star deposit (3) is in the NW $\frac{1}{4} \mathrm{NE} \frac{1}{4}$, sec. 22 , T. 46 N., R. 14 E., Mount Diablo base line and meridian. The perlite is gray and has a pearly luster. The perlite fragments do not exceed 4 inches in diameter. A few bands of reddish agglomerate transect the deposit. (O'Brien, 1948, p. 350.).

\section{Mono County:}

Dark-gray perlite (18) occurs as irregular lenslike bodies in tuff and brownishpink rhyolite north and east of Casa Diablo Hot Springs. (Chesterman, 1950, p. 200.)

\section{Napa County:}

A perlite deposit (11) is reported 2 miles east" of the railroad station at Rutherford, 60 miles north of San Francisco, secs. 32, 33, 34, and 35, T. 8 N., . R. 5 W., Mount Diablo base line and meridian. The perlite occurs in flows which range from a few tens of feet in the southern end of the deposit to several hundreds of feet at the northern end. It lies upon tuffs and conglomerates and is overlain by tuffs and däcite of Pliocene age. Two deposits (12) have been reported along State Highway 29 ; about 5 miles east of Napa; one is in a roadcut on the edge of the Basalt Rock Company's Mount George pumice deposit, and the other is in a roadcut about half a mile to the east. These deposits may be of commercial value. (Davis, 1948, p. 171.)

The Perlite Aggregates, Inc., deposit (10) is in the Conn Valley near St. Helena. It covers 272 acres and is said to be of good quality. (Utley, 1951, p. 76.)

A deposit (13) of perlite lies 2 miles southeast of Bismark Knob. (Chesterman, 1950; " p. 200.)"' 
Riverside County:

In the Little Chuckawalla Mountains (48) about 38 miles southwest of Blythe large deposits of perlite are found in Tertiary volcanic rocks. (Chesterman, 1950, p. 200.)

\section{San Benito County:}

A large perlite deposit (21) crops out at Pinnacles National Monument. The rock is dark gray, has well developed perlitic structure, and contains small globules of black obsidian. It is found along the Chalone Creek about threequarters of a mile north of an abandoned Civilian Conservation Corps camp. The perlite ranges in thickness from 30 to 60 feet and surrounds a central plug - of rhyolite. Other deposits are in the northern part of sec. 15 and along Chalone Creek. (Calif. Div. Mines Min. Service, 1953, p. 6.)

\section{San Bernardino County:}

The following information on San Bernardino County was taken from Chesterman, 1950, p. 201, except where otherwise indicated.

San Bernardino County contains more perlite deposits than any other county in California. Most deposits are in either Miocene or undifferentiated Tertiary volcanic rocks. Deposits (32) in the hills a few miles north of Pilot Knob are part of a series of volcanic rocks which include tuffs, agglomerates, breccias, andesite and basalt flows, and basalt dikes. These rocks dip gently westward and are underlain by tuffaceous lacustrine sediments. The perlite flows range in thickness from a few tens of feet to more than 100 feet. Deposits (33) of perlite similar to those near Pilot Knob are exposed in the vicinity of Black Canyon, which is 18 miles south of Pilot Knob, and 4 miles north of Coolgardie Camp. These flows are associated with basalt flows, tuffs, agglomerates, breccias, and lake deposits, perhaps not older than middle Miocene.

Large deposits (36) of perlite are exposed in. Miocene volcanic rocks 6 miles north of Klondike and 12 miles north of Bagdad, stations on the Santa.Fe railway. The gently to steeply dipping flows in which the perlite occurs are 100 feet thick in some places, and are between tuffs and pumiceous rhyolite.

On Clipper Mountain' (Tucker and Sampson, 1943, p. 535, and Chesterman, 1950 , p. 201) about 18 miles northeast of Amboy, perlite occurs in a group of volcanic and pyroclastic rocks (38). It is overlain by platy rhyolite and underlain by brecciated perlite, tuffs, and sandstone.

Large deposits (39) of perlite are in the Turtle Mountains about 30 miles southwest of Needles. The perlite is found in flows ranging in thickness from. a few feet to more than 20 feet. Angular and rounded perlite fragments are associated with tuffs and pumiceous perlitic rhyolite in these flows. Andesite and basalt dikes in places cut the other volcanic rocks and tuffs.

Irregular lens-shaped deposits (35) of perlite are in the Newberry Mountains, 6 miles south of Newberry.

Perlite (37) has been found on the southeast slope of the Granite Mountains 1 mile east of the Amboy-Kelso road, and 18 miles northeast of Amboy in sec. 10(?), T. 8 N., R. 13 E., San Bernardino base line and meridian. (Tucker and Sampson, 1943, p. 535.)

\section{Siskiyou County:}

Large deposits of perlitic rhyolite are on Mount Hoffman in the Medicine Lake Highland (Chesterman, 1950, p. 201). These deposits are underlain by basalts and andesites. The deposits are probably in the form of a dome built up by successive outpourings of viscous perlitic rhyolite. The flows range from 50 to 150 feet in thickness.

\section{Solano County:}

Perlite deposits (14) are found along Green Creek, sec. 15, T. 5 N. ; R. 3 W., Mount Diablo base line and meridian, about 5 miles north of Cordelia:: The perlite 
is grayish white to dark gray. Tuffs and flows of rhyolite and basalt of the Sonoma volcanics (Pliocene) are associated with the perlite. It occurs as ir= regular lens=shaped bodies and ranges from 10 to 50 feet in thickness and many hundreds of feet long. (Calif. Divi. Mines Inf. Service, 1951, p. 2.)

\section{Sonoma County:}

On the Annadel Farms; near Lawndale (8), two types of perlite occur, one contains obsidian, and the other does not. Light=gray perlite is found in an old railroad cut 3 miles northwest of Lawndale. The lenticular deposit occurs in a platy rhyolite. In some places the perlite is brecciated, and contains black obsidian and clay, A perlite flow of variable thickness is exposed at a flagstone quarry on the Annadel Farms. This deposit underlies tuff and basalt and does not contain obsidian: (Chesterman; 1950; p. 202.)

Perlite occurs as flows and lenticular bodies in rhyolitic tuff on the A. W. Frazier property (7) in secs, 1 and 11, T. 6 N., R. 6 W., Mount Diablo base line and meridian, about 4 miles northeast of Glen Ellen and State Highway 12. The flows are above silicified rhyolite tuff and are overlain by riebeckite rhyolite. The perlite is light gray; the upper part of the flow contains spherulites of radi=. ating fibers of quartz and potash, also feldspar and lithophysae.

An extensive deposit (6) of perlite is found in the NE $\frac{1}{4} \mathrm{Sec}$. 7, T. 6 N. , R. $7 \mathrm{~W}$., Mount Diablo base line and meridian, about three-fourths of a mile north of the Steuben School: The perlite is light gray and contains quartz, feldspar; and biotite: "It forms a flow of variable thickness and length and overlies rhyolite tuffs which; in turin; are overlain and underlain by flows of dark gray, platy, massive andesite. " (Chesterman; 1950, p. 81=82:)

\section{COLORADO}

All information on Colorado was obtained from Bush (1951, p. 326=331) except where otherwise indicated.

\section{Chaffee Countity}

The Nathrop (Ruby Mountain) deposit (2) is in secs, 11, 12, and 13, T. 15 S. , $\dot{R}_{\mathrm{a}} 78 \mathrm{~W}_{1}$, at an altitude of about 8,000 feet. It is on the east side of the Arkansas River; and less than a mile east of the Denver \& Rio Grande Western Railroad at Nathrop. A perlite flow believed to be more than 15 feet thick is along the east side and nortti end of Ruby Mountain.

\section{Cuister Countyi}

The Rosita Hills deposit (6) is in secs, 32 and $33, T, 22 S_{1}, R_{0} 71 \mathrm{~W}$, , and in secs. 5 and $6, T \cdot 23 S_{1}, R_{2} 71 W_{0}, \frac{1}{2}$ to 2 miles south and southwest of Rosita, at an altitude of about 8,700 feet. The perlite is in a flow, 40 to 75 feet thick, overlain by rhyolite and underlain by bedded tuft. Overburden ranges from 6 inches to 2 feet in thickness.

It is said that a reddish=brown perlite deposit occurs north of the towns of Westcliffe and Silver cliff.

\section{Eagle Countity:}

A perlite deposit is on the south ând east flanks of Basalt Mountain, north of the town of Basalt.

\section{Fremoñt Countỹ}

Gray pertite with scattered pellets of obsidian occurs at the north end of Ruby Mountain: (Wood, 1948, p; 11:)

\section{Grand Couintỹ:}

Perlite deposits have been reported on the western slope of the Front Range, and north of the town on stiliwater. 
Gunnison County:

The Morning Star deposit (3) is in sec. 35(?), T. 50 N., R. 5 E: about $9 \frac{1}{2}$ miles from the Denver \& Rio Grande Western Railroad at Sargents. It is at an approximate altitude of 9,800 feet. Two dikes are reported to dip rather steeply. The larger dike, granular and vesicular, is about 50 feet thick. The smaller dike is about 5 feet thick.

\section{Rio Grande County:}

A perlite deposit is reported between Del Norte and Monte Vista.

\section{Saguache County:}

The Prossers Rock deposit (7) is in secs. 6 and 7, T. 47 N., R. 5 E., at an altitude of about 9,500 feet. Perlite is exposed on the east side of Prossers Rock, on a ridge 300 to 350 feet above Razor Creek. At the top of the flow the perlite is 7 feet thick, and another layer 7 feet thick occurs at the bottom of the flow. Between these exposures, perlite and a small amount of obsidian are found. Perlite is estimated to be about 60 to 70 feet thick, interbedded with some obsidian.

Cochetopa Dome deposit (8) is in sec. 36, T. 46 N., R. 2 E., at an altitude of about 9, 700 feet, 1 mile north of State Highway 114, and about 24 miles south of the Denver \& Rio Grande Western Railroad at Parlin. Perlite flows exposed in the south -facing cliffs of the Cochetopa Dome have a thickness of about 45 feet. The cliffs are about $1 \frac{1}{2}$ miles long.

Cathedral deposit (9) is in the SW $\frac{1}{4}$ of T. 45 N., R. 1 W., at an altitude of about 10,500 feet. The flow crops out in a 300-foot cliff, most of which is said to be perlite.

Other deposits reported in this county are south of Prossers Rock deposit, north of Cochetopa Dome deposit, in an area in the north-central section of the county, west of Needle Creek, and west of Mineral Hot Springs.

\section{NEVADA}

All information on Nevada was taken from Cochran (1951, p. 8-18) except where otherwise noted.

\section{Clark County:}

The NuLite Insulated Homes, Inc., mine (24) is 12 miles west of Searchlight and 21 miles east of Ivanpah, Calif. The property covers 280 acres extending into San Bernardino County, Calif. It crops out in an area 2 miles long and 1 mile wide; its average thickness is about 50 feet.

The Searchlight Insulation Products mine (23) is in the S $\frac{1}{2}$ sec. 9 and $N \frac{1}{2}$ sec. 16, T. 28 S., R. 63 E., and comprises 180 acres. The deposit consists of two flows which include thin layers of andesite or dacite. Overburden is thin. One flow is 1,500 feet long, 240 feet wide, and 21 feet thick, whereas the other is 2,600 feet long, 500 feet wide, and averages 100 feet thick.

The U. S. Perlite Manufacturing Company deposit (20), comprising 10 placer claims, is about 20 miles south of Goodsprings. Limestone and dolomitic limestone surround the deposit, which ranges from 15 to 200 feet in thickness. The perlite is black, glossy, and granular, mixed with reddish dacite and obsidian.

The Morelight Company deposit (25) and the Basic Materials Company deposit (26) are near Searchlight (O.S. North, U. S. Bur. mines, personal communication), and the Continental Engineering Service deposit (19) is near Las Vegas (Chem. \& Metall. Eng., 1945, p. 170).

\section{Lincoln County:}

The Kopenite, Inc., deposit (14) is 35 miles southwest of Caliente, approximately in T. $4 \mathrm{~S}$., R. $63 \mathrm{E}$. The deposit is a large flow of perlite resting upon an andesite flow. Pellets of obsidian, which are not harmful to the expanded 
material, are included in the perlite. The deposit is 8,500 feet long, 800 feet wide, 20 feet thick, and has very little overburden.

The Robb deposit (15) is about 14 miles southwest of Elgin. The deposit occurs between two porphyry flows.

The Johnston and Fitchett deposit (16) underlies 480 acres in the $S \frac{1}{2}$ secs. 27,

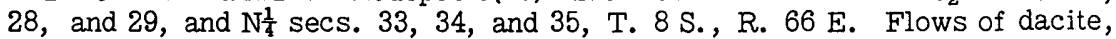
rhyolite, and perlite have a thickness greater than 1,000 feet. The flows are distorted; dips range from horizontal to $80^{\circ}$. The perlite occurs as lenticular beds in dacite and rhyolite or both ranging from 4 to 50 feet thick.

The Snow deposit (9) comprises two lode claims in the Goldsprings mining district, in sec. 23, T. 1 N., R. 70 E. The perlite at one location is 1,320 feet long, 600 feet wide, and 50 feet thick. It is part of a dacite flow. 'The perlite is glassy, greenish black, and has a considerable amount of contamination. At the second location the perlite flow is 2,640 feet long, 1, 320 feet wide, and 100 feet thick. It is granular, blackish gray, and contains very little contaminating material.

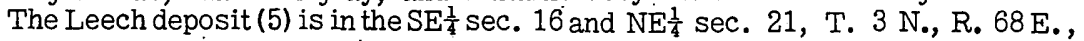
23 miles northeast of Pioche. The property comprises two placer claims of 40 acres. The deposit, overlying an andesite flow, is 600 feet long, 500 feet wide, and 50 feet thick. The perlite is dark gray to black, glassy, and contains little contaminating material.

The Free deposit (7) is in secs. 5 and 6, T. 2 N., R. 69 E., 14 miles northeast of Pioche. A light-gray perlite overlies a dacite flow. Many stringers of dacite are in the perlite, but generally it is free of contaminating materials. The deposit is 800 feet long, 300 feet wide, and 25 feet thick.

The Eccles and Minto deposits (12) are in secs. 7, 8, and 17, T. 4 S., R. $63 \mathrm{E}$., less than 6 miles east of Caliente. The two deposits are no doubt one continuous bed underlain by a rhyolite flow. The deposit is flat-lying except in the lower part of the flow. The Eccles deposit is of very good quality perlite with very little overburden. The Minto deposit is of very good quality granular perlite, and most of it is capped with andesite.

The Acoma deposit (13) occurs in secs. 22 and 23, T. 5 S., R. 70 E., 6 miles south of Acoma. The perlite overlies and is partly covered by a dark-reddish andesite, and is comparatively free from overburden.

The Hollinger deposit (6) comprises three placer claims in secs. 3 and 10, T. 3 N., R. 68 E. It occurs between two vitreous flows. There is little overburden.

The Combined Metals Reduction deposit (Fairview) (8) occurs in the foothills of Ely Range in the SW $\frac{1}{4}$ sec. 28,T. 4 N., R. 69 E., about 26 miles north of Pioche.

Other deposits in the County are the Boykin (Pulcepher) deposit (17) southeast of the Acoma deposit, 7 or 8 miles from the Union Pacific Railroad (Cochran, 1951 , p. 9); Grant deposit (10) $4 \frac{1}{2}$ miles from Caliente (Lenhart, 1950, p. 99); and Delamar Company deposit (11) near Caliente (O. S. North, personal communication).

Nye County:

One perlite deposit in the Doughboy Group (18) is 5 miles from Beatty, and another is south of Fallon in the Beatty district. (Min. World, 1949a, p. 80.)

\section{Pershing County:}

Perlite deposits (3) are the United States Gypsum Company mine near Lovelock (Eng. Min. Jour., 1950, p. 128), and a deposit in Cow Creek area, at the northern end of Seven Troughs Range, northwest of Lovelock (Pit and Quarry, 1949, p. 57).

\section{NEW MEXICO}

Much of the information on New Mexico was furnished by Eugene Callaghan, director of New Mexico Bureau of Mines. 
Grant County:

The McDonald ranch deposit (12) is about 16.5 road miles northeast of Separ, in secs. 1, 2, 11, and 12, T. 22 S., R. 15 W., and secs. 18, 19, 29, and 30, 32 T. 22 S., R. 14 W. Perlite crops out in a narrow belt extending northwest for more than 9 miles along a shallow canyon and adjacent slopes. The perlite occurs as a tabular flowlike mass, having a maximum exposed thickness of 100 feet. It is locally underlain by stratified tuffs and breccias, and overlain by welded tuff(?), spherulitic rhyolite, and basalt. Although highly variable in color and texture, the segments of commercial value consist of pale-gray to dark bluish-gray glass with pronounced perlitic structure. The El Paso perlite Company has been developing a southeastern segment of this deposit.

The Pyramid Mountains deposit (11), about 8 miles south-southeast of Lordsburg, is exposed in an arcuate outcrop that encircles the north, west, and southeast faces of the Leitendorf Hills. The glass attains a maximum thickness of several hundred feet in the west face of the hills. It is capped by breccia on the north, bounded by, and perhaps partly underlain by, a massive, welded felsite breccia on the west, and capped by crumpled, flow-banded rhyolite on the southeast. The glass ranges from an unfractured type to that having a finely perlitic texture, and the color ranges from resinous darkbrownish-red to olive and dark green. Physical properties and chemical analyses indicate a perlitic pitchstone phase of sodic rhyolite. Parts of the deposit have been commercially exploited.

\section{Iuna County:}

The Hermanas deposit (13) is meagerly exposed in a group of low hills about three-fourths of a mile north of Hermanas, a siding on the Southern Pacific Lines. The rock exposed in and adjacent to a shallow shaft consists of variably devitrified perlitic pitchstone of dark brownish red to olive green and of resinous luster. The glass is locally capped by rhyolitic flows and is cut by lithoidal flow bands, and ribs and irregular masses of felsite. This deposit appears to have little commercial value, because of the large proportion of interlaced lithoidal material.

\section{Sandoval County:}

Deposits (3) of volcanic glasses occur at a number of localities in the Jemez Mountains. The more accessible of these are in Cochiti, Bland, and Peralta Canyons, approximately 28 miles west of Santa Fe. A deposit at Bear Springs is about $8 \frac{1}{2}$ miles farther west.

The Bland Canyon deposit (2) consists of a series of variably cemented rhyolitic breccias, which are overlain by massive Bandelier welded tuff. Irregular ribs and dikelike masses of dense, flow-banded vitreous to pitchy, pale-gray to dark-green and black glass cut the breccia. The structure of the deposit suggests that it is a breccia dome.

In Peralta Canyon, sec. 28, T. 17 N., R. 5 E., a perlite mass (4) that exhibits gradational contacts with lithoidal rhyolite is exposed. The perlite is overlain on the east by stratified tuffaceous sands and gravels containing boulders of perlite. The internal structure of the perlite body is typified by conspicuous, complexly arranged flow-banding, in parts of which glassy to lithoidal porphyritic rhyolite is interleaved with porphyritic perlite. Local zones of autobreccia truncate the flow banding. A few small segments of the mass consist of pale-gray, highly perlitic to pumiceous perlite of commercial grade.

In the vicinity of Bear Springs (5), T. 17 N., R. 4 E., highly vitreous, green to gray perlite is poorly exposed at several places on a broad, rubble-covered slope, and in adjacent shallow canyon walls. Brecciated zones in the glass are cemented by reddish glass and lithoidal rhyolite. Many parts of the mass are contaminated by hydrothermally devitrified glass, and by an abundance of spherulitic nodules that contain cores of chalcedony and opal. The prevalence of impurities, together with the high costs of transportation from the area, will inhibit development of this deposit. 


\section{Sierra County:}

Deposits (10) of perlite crop out in several areas west of Lake Valley. A deposit about 1 mile southwest of Lake Valley contains an irregular flow sheet of pale-gray to dark bluish-gray perlitic glass. The glass is capped by crumpled, platy, felsitic rhyolite, and underlain by rhyolitic tuffs and breccias. The upper part of the perlite body contains an abundance of conspicuous spherulitic and lithoidal flow bands. Future exploitation of this deposit would appear to be limited to a very small-scale, selective mining program.

\section{Socorro County:}

The Great Lakes Carbon Corporation deposit (8) is about 3 miles southwest of Socorro, on the southeastern flank of the Socorro Mountains. Operations were begun in 1949 on this deposit which has since become one of the largest domestic sources of crude perlite. The deposithas the form of a glass dome, with diameters of approximately one-third and one-half mile, and an exposed vertical continuity of more than 450 feet. The eastern and western margins of the deposit are defined by high-angle normal faults, between which the perlite mass forms a horst block. To the north and south, the perlite is overlain by a sequence of breccias and massive to thin-bedded, weakly to highly indurated vitric tuffs that grade upward into clays, sands, gravels, and their indurated equivalents. The entire sequence was faulted, beveled, and covered by a sheet of Quaternary(?) basalt, which has been largely stripped off by subsequent erosion. The glass is a pale-gray to buffish-gray, conspicuously flow-banded, pumiceous rock of rhyolitic composition. It is remarkably uniform in quality throughout most of the deposit except for a segment at the northeastern margin, where it is interlayered with lithoidal rhyolite flow bands and, in places, has been altered to montmorillonite.

Several deposits (9) of volcanic glass are in the volcanic terrain south of Magdalena and west of the Magdalena Mountains. One of the larger of these is in secs. 14 and 23, T. 3 S., R. 4 W., where perlite is exposed in the east wall of Agua Fria Canyon. The perlite occurs as a tabular mass as thick as 200 feet, overlying porphyritic-spherulitic rhyolite along an intergradationalcontact. An ascending sequence consisting of about 460 feet of perlite breccias, stratified pumiceous tuffs, and two distinct rhyolitic flows with black vitrophyre basal selvages overlies the perlite. The perlite is predominately a pale-gray, conspicuously porphyritic rock of fine-grained perlitic structure, and rhyolitic composition. The occurrence of bands of abundant spherulites and bands and zones of complete hydrothermal devitrification of the glass in this deposit seriously depreciate its commercial potentialities.

\section{Taos County:}

- At No Agua Mountain, approximately 7 miles north of Tres Piedras, an extensive deposit (1) of perlite is being exploited by two companies. No Agua Mountain embraces a cluster of four subconical peaks encircling a breached central valley. The rocks composing these peaks include several textural varieties of volcanic glass, massive rhyolitic breccias, and other fragmental volcanics. The overall form and structure of the mass suggest that it originated as a volcanic dome. Gray to buff, flow-banded, pumiceous glass, with physical characteristics similar to those of the Socorro perlite, forms commercialgrade bodies that extend over a large area.

\section{Valencia County:}

The United States Gypsum Corporation is mining a perlite deposit (6) about 8 miles northeast of Grants, at the eastern end of Grant Ridges. The rocks in this area, which is on the western margin of the Mount Taylor volcanic field, consist of sandstones and shales of the Mesaverde formation, pumiceous tuff, felsitic rhyolite, and several types of volcanic glass. The sequence is capped by thin basalt flows and is intruded by a basaltic neck at one point. Among the several types of volcanic glass are two of commercial quality: a pale bluishgray, highly perlitic type, and a massive, pale-gray, pumiceous type. The 
pumiceous glass crops out in a series of spur ridges that extend northward and northeastward from below a cliff of massive, felsitic rhyolite. The largest of these spurs is about 200 feet high.

\section{OREGON}

\section{Baker County:}

Perlite (3) occurs in the southern part of the county, in the Dooley Mountains (Mason, 1951, p. 14). In the vicinity of Pleasant Valley, it is associated with tuffs of probable Pliocene age (Allen, 1946, p, 2).

\section{Harney County:}

Perlite has been found on Juniper Ridge (4) southwest of Burns (Mason, 1951, p. 14). In the Steens Mountains (5) rhyolite flows and intrusive bodies occur with perlitic margins which are probably of Pliocene age. In the Harney Basin perlite occurs in rocks of the Danforth formation (Pliocene). (Allen, 1946, p. 2.)

\section{Lake County:}

The Paisley deposit (6) is 10 miles south of Paisley, on the highway to Lakeview. (Mason, 1951, p. 14.)

\section{Malheur County:}

The Sheaville deposit (8) is in the eastern part of the county (Mason, 1951, p. 14); another deposit (7) is in the Cedar Mountains near Owyhee (Allen, 1946, p. 9).

The Lady Frances mine (2), now abandoned, is on the Deschutes River near Frieda in sec. 24, T. 6 S., R. 13 E. (Allen, 1946, p. 10). The perlite is in the Clarno formation (Eocene), according to Allen (1946, p. 2). This information is divided by a strong unconformity between andesitic tuffs, breccias, and flows and an upper rhyolitic series in which the perlite occurs. More recent investigations (A. C. Waters, 1955, personal communication) have established the fact that the unconformity recognized by Allen can be traced far to the east. To the east it definitely separates the Clarno from the John Day (Oligocene); and is an excellent stratigraphic marker. Therefore, the rhyolite and associated perlite at Frieda is John Day, but the andesites beneath the unconformity reported by Allen are truly Clarno. Another deposit, known as the Axford-Hunt (1), is in the SW $\frac{1}{4}$ sec. 16 and extends into $\mathrm{SE} \frac{1}{4}$ sec. 17, T. $6 \mathrm{~S} .$, R. $14 \mathrm{E}$. (Mason, 1951, p. 14; Allen, 1947, p. 61).

\section{Hudspeth County:}

\section{TEXAS}

Thin beds of pitchstone, vitrophyre, and perlite occur with rhyolite near Eagle Spring and Panther Bluff (6). Thin beds of welded tuff interbedded with tuffaceous sediments are found south of Wind Canyon. (Gillerman, 1953, p. 53.)

\section{Beaver County:}

\section{UTAH}

The Utco Products Company deposit (7) is in T. 27 N., R. 9 W., about 14 miles northeast of Milford. The perlite is light gray-blue and occurs in flows. (Cochran, 1951, p. 20.)

Perlite, Inc., is reported to own a deposit (8) near Milford (R. J. Roberts, personal communication).

\section{Millard County:}

The Huntsman deposit (4), T. 23 S., R. 8 and 9 W., is less than 5 miles east of the Union Pacific Railroad's main line between the stations of Cruz and Bloom Siding, and about 23 miles west of Kanosh. Part of the perlite is covered by a rhyolitic flow, but only a slight intermingling of rhyolite with the perlite occurs in the exposures. (Cochran, 1951, p. 18-19.) 
The Utah Pumice and Perlite Company deposit (6) is 6 miles north and east of Black Rock and 30 miles north of Milford. It comprises 40 acres of patented mining property and 120 acres of placer claims. Perlite and pumice occur in a dacitic flow. The perlite is light gray to tan, and semipumiceous. (Cochran, 1951, p. 19-20.)

Other deposits are the Christensen Construction Company's deposit (5) near Pumice, and the Day deposit (3), $2 \frac{1}{2}$ miles from Bloom (R. J. Roberts, personal communication).

Washington County:

The Wilson deposit (10) is reported to be near Veyo (R. J. Roberts, personal communication).

\section{WASHINGTON}

All information about the State of Washington was obtained from Huntting (1949, p. 7-60) unless otherwise indicated.

No perlite deposits in Washington have been used commercially. Most of them are perlitic vitrophyre which cannot compete with the higher grades of perlite.

\section{Chelan County:}

Three formations are in the Wenatchee area (2). The oldest rocks are a thick series of arkosic sandstones and coarse conglomerates of the Swauk formation (Eocene). Intruded into the Swank formation are dikes, sills, necks, and perhaps small laccoliths, of material ranging in composition from basalt through andesite, dacite, and rhyolite. The silicic rocks are light in color. Some of the necks have a glassy groundmass, and some have perlitic glass phases.' The intrusive rocks cut the Swauk formation of early Eocene age. The Yakima basalt of Miocene age overlies unconformably both the Swauk and the intrusive rocks.

The Rooster Comb and Dry Gulch deposits are in the Wenatchee area, near the northeastern end of the ridge between Dry Gulch and Squillchuck Canyon. The Norco Well deposit is on Wenatchee Heights, less than 2 miles southeast of the Rooster Comb deposit. These three deposits are in a nearly straight line and are within an area of 25 square miles.

The Dry Gulch deposit consists of blue-gray perlite exposed on the south side of a dome-shaped hill rising 150 feet above the valley level at the mouth of Dry Gulch. The deposit has been classified as soda-rhyolite and dacite porphyry with a perlite margin.

The Rooster Comb deposit, a blue-gray perlite body, is exposed at the southeast corner of the $N W \frac{1}{4} N^{\frac{1}{4}}$ sec. $22, T .22 \mathrm{~N} .$, R. $20 \mathrm{E}$. The perlite probably is a facies of the dacite which surrounds it. This deposit is similar to the Dry Gulch deposit.

The Wenatchee Heights deposit consists of devitrified perlitic rhyolite. Phenocrysts of quartz and feldspar comprise 5 percent of the material.

\section{Klickitat County:}

The Satus Creek deposit (3) is on the Yakima Indian Reservation in Sw $\frac{1}{4}$ sec. 9, T. 6 N., R. $16 \mathrm{E}$. It is on the east bank of Satus Creek at an altitude of 4,700 feet, about $1 \frac{1}{2}$ miles north of Indian Rock. The material is light gray and has a distinctive sheen, which may result from refraction of light by the thin, onionlike layers of perlite. Some of the exposed perlite is very vesicular, individual vesicles less than 1 millimeter in diameter being so numerous as to give the rock a pumiceous structure.

, The following perlite deposits are located in the white River basin (1) on the western side of the Cascade Mountains, 20 miles north of Mount Rainier and approximately 40 miles east of Tacoma.

\section{King County:}

Near Cyclone Creek gray perlite is exposed at an altitude of 2,375 feet on the south slope of Grass Mountain. The deposit is in SE $\frac{1}{4} \mathrm{SW}^{\frac{1}{4}} \mathrm{sec} .27, \mathrm{~T}$. 20 N., 
R. $8 \mathrm{E}$., less than one-half mile west of Cyclone Creek and 1 mile north of White River. Andesite is associated with the perlite. The unweathered perlite is black, but after weathering, the color changes to light gray. The perlite has a rough granular texture and flow-banded structure. Laboratory tests show that this perlite has an average water content of 2.86 percent; the $\mathrm{SiO}_{2}$ averages 81.34 percent. After expansion, the Cyclone Creek perlite is a butf color, which is not actually detrimental, although white is the most desirable.

\section{Pierce County:}

The Cliff (White River) deposit is in the SW $\frac{1}{4}$ sec. 11, T. 19 N., R. 8 E. Greenish-gray and black perlite 4 feet thick overlies soft tuff and is exposed for about 50 feet; the size of the entire deposit is not known. This deposit is probably a part of a huge landslide block. The perlite has a conchoidal fracture and a glassy to resinous luster. The material tested from these Miocene volcanic rocks expanded only slightly when heated. (Valentine, 1949, p. 67; Huntting, 1949, p. 50.)

The Divide (Mineral Creek) deposit is in the center of sec. 14, T. 19 N., R. $8 \mathrm{E}$. The greenish-black perlite is exposed to a height of 20 feet for a distance of 100 feet in an old railroad cut. The perlite body is irregular and is mixed with bentonitic clay. Four feet of silicified andesite overlies the perlite. The perlite is vitreous and is characterized by flow-banding and well-developed perlitic structure.

Two masses of black perlite are exposed along a steep hillside on the north side of Milky Creek, a tributary to Clearwater River. These deposits are near

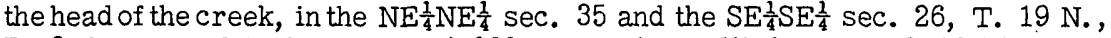
R. 8 E., at an altitude of about 4,000 feet. The perlite has a conchoidal fracture and a glassy to resinous luster.

Many minor occurrences of perlite are in andesite flows in the White River area. However, the large number of spherulites cause this perlite to be unsuitable for commercial use.

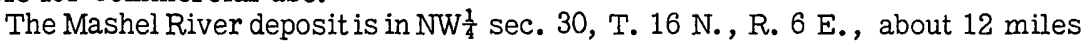
west of Mount Rainier. It is at an altitude of about 1,900 feet. The average width of the deposit is about 10 feet. The deposit is in a flow showing platy structure and having little banding. About 10 percent of the rock is white to colorless small feldspar crystals in the black glass. The Mashel River deposit is associated with the Keechelus andesitic rocks and may be of commercial interest.

Occurrences of perlite have been reported in Benton, Clark, Cowlitz, Skamania, and Yakima Counties. Very little has been published about these deposits. (Valentine, 1949, p. 67; also Huntting, 1949, p. 57-60.)

\section{WYOMING}

\section{Yellowstone National Park:}

Perlite occurs in bands of dark-gray rhyolite which forms a cliff on the east side of the Firehole River, opposite Excelsior Geyser and the Midway Geyser basin (1). These bands are alternately vitreous and lithoidal. In some places the centers of the perlitic shells are black glass with surrounding thin, lightgray shells. Perlite occurs in this manner in many localities in Yellowstone Park. (Diller, 1898, p. 151.)

\section{RESERVES}

Very little information has been published on the reserves of perlite in the United States. This is due presumably to the fact that the use or perlite is relatively new. Much field work needs to be done to locate workable deposits of perlite, and more exploratory work is necessary before a reasonable estimate of reserves can be 
given. However, a few companies have published estimated reserve figures.

Sixteen deposits of perlite in Nevada and Utah have been examined and described by Cochran (1951, p. 23). These deposits are estimated to have total reserves of more than $4,000,000$ tons of suitable quality material. Of the deposits examined, only 6 were in production and 2 others were being considered for development.

The reserves of the Rosita mining district ${ }^{1}$ near Westcliffe, Colo., are reported to be $20,000,000$ tons. However, a considerable part of the district is of little importance because of transportation difficulties.

In the mountain ranges 4 miles southwest of Socorro, $\mathrm{N}$ Mex. (Min. World, 1950, p. 29), a perlite deposit is reported to contain many millions of tons. Deposits in Grant County, New Mexicc (Pit and Quarry, 1953, p. 162) are estimated to contain approximately 2,000, 000 tons of high-grade perlite.

The Fairview, Hollinger, and Grant mines in the vicinity of Caselton, Nev. (Lenhart, 1950, p. 99), presumably have manj millions of tons of perlite in reserve. The Grant mine alone is reported to contain more than 14,000,000 tons.

A deposit on the Spring Valley ranch of Fred Holt near St. Helena, Napa County, Calif. (Pit and Quarry, 1951, p. 66), is reported tc contain $5,000,000$ tons of perlite.

The Perlite Aggregates, Inc., deposit (Utley, 1951, p. 76), in the Conn Valley near St. Helena, Napa County, Calif., is said to contain 125, 000, 000 tons of perlite. Quarrying was started April 10, 1951. This company's original plant produced 900 bags a day, but with installation of a second unit, the production was increased to 2,000 bags daily.

\section{MINING, MILLING, AND PROCESSING}

Commercial perlite deposits in the United States are on or close to the surface and open-pit methods of quarrying are generally used. Mining is simple and inexpensive, with disposal of overburden and transportation in general being the major problems.

Milling of perlite centers on the comminution of the rock to the desired screen size. Both wet and dry processes are used (Gustafson, 1949, p. 315). The wet process reduces the dust hazard but requires about 15 tons of water per ton of perlite. Most companies prefer the dry method.

Although there has been no standardization of sizes, the following sizes are commonly accepted as satisfactory for delivery to the trade for expansion (Wilfley and Taylor, 1950, p. 82):

Concrete aggregate: Minus 8 mesh, plus 30 mesh (15 percent plus or minus).

Plaster aggregate: Minus 14 mesh (or minus 16), plus 50 mesh (15 percent plus or minus).

Plaster aggregate: Minus 20 mesh (maximum 25 percent minus 100 mesh).

\footnotetext{
${ }^{1}$ Taylor, C. W., 1949, Perlite-champion of the lightweights, address made to Colorado Mining Assoc., Denver, Feb. 1, 6 p.
} 
Fines: Minus 30 mesh (maximum 10 percent plus 30 mesh).

For information on processing the reader is referred to Murdock and Stein (1950, p. 111-116).

\section{ECONOMIC ASPECTS}

The post-World War II building activity brought about increased research in construction materials (Gustafson, 1949, p. 313). The trendwas toward lighter weight aggregates to relieve the dead load on steel frame buildings. As search for lighter weight aggregates progressed, other useful qualities such as sound and heat insulation, nailability and lightness, with consequent saving in labor costs, became important considerations. The search finally led to the expansion of perlite.

According to the Perlite Torch (1951; p. 1), perlite cannot compete with structural sand and gravel when a moderately high compressive strength for concrete is required, but when lightweight, fire-resistant insulating concrete is desired, perlite has much to offer.

Perlite-gypsum plaster has a relatively low coefficient of thermal conductivity which retards heat transfer (Perlite Institute, 1950). Such a plaster combined with metal lath to a thickness of $2 \frac{1}{2}$ inches has achieved a rating of 2 hours' resistance to heat, flame, and smoke in recent tests in Chicago by the Underwriters' Laboratories, Inc. In addition, fireproofing of steel columns and floor beams by $1 \frac{3}{4}$ inches of perlite-gypsum plaster and metal lath has been rated at 4 hours safe protection by the same laboratories.

Perlite is used as an insulating concrete to fill ship bilges (Perlite Torch, 1952, p. 4). The condensation of water and seepage through seams causes water to collect in ship bilges; this problem has been solved by filling the bilges with perlite concrete, and then the large bilge covers can be discarded to reduce the dead weight. It has been found (Perlite Torch, 1951, p. 2) that when perlite is substituted for ordinary foundry sand to surround the pouring riser, the insulating qualities of perlite prevent excessively rapid cooling of this part of the mold, with consequent improvement of the casting.

Loose perlite (Ralston, 1946, p. 9) is also used as an insulating material elsewhere. It can be either poured or blown into place between walls already constructed or into hollow concrete masonry; used as a wall filling, it will not compact but will remain loose as originally placed.

In addition to having a low bulk density and being a good heat and sound insulator, perlite is mildew- and vermin-proof. It will not deteriorate or give off any objectionable odor when wet, and being nonhygroscopic it has a low absorption. Expanded perlite (Barberii, 1949 , p. $280,283-284$ ) is used in drilling oil wells to seal off the loss of oil through porous formations.

Perlite fines (Atlantic Pérlite Co., no date, 5 p.) resulting from processing, are that part of the material in the size range of minus 100 mesh. There has been little use for this material but with its 
application to oil-well drilling and as fillers and filters they are finding their place in industry.

Perlite is competitive with pumice, pumicite, bloated shales and clays, and vermiculite. Prices for perlite as of June 1954 are as follows (Min. World, 1954, p. 86): Crude, f. o.b. mine per short ton, $\$ 3-\$ 5$; plaster grades, crushed and sized, f. o. b. plants per short ton, $\$ 7-\$ 9$; and concrete grades, crushed and sized, \$6 -\$8. Expanded perlite is packed in multiwalled bags and is usually sold by the bag, ranging in price from 15 to 40 cents a cubic foot (North, O. S., personal communication).

Many factors must be taken into consideration to evaluate properly the profitable marketing of perlite. The size of the deposit and the minimum cost necessary to remove overburden are major items. Transportation facilities to the loading point and sizing plant must be reasonably good. Expansion characteristics, as they relate-to the softening range, ratio and temperature of expansion, and color of product, must be determined. Such factors as compressive strength, mortar strength, absorption rate, freezing and thawing, thermal expansion, and thermal conductivity must also be determined: Because perlite is found only where geologically recent volcanic activity has occurred in the Far Western States, freight is a vital consideration in the production of perlite. Economics demands that crude perlite be shipped to expanding plants scattered throughout the United States close to consumers' markets. Only after it has been brought close to the distribution centers is it expanded and its bulk density drastically reduced.

\section{KEY TO INDEX MAP (PL. 44) OF PERLITE RESOURCES OF THE UNTTED} STATES (INCLUDING PROCESSING PLANTSS)

\section{Arizona:}

Deposits and processing plants in Mohave, Yuma, Maricopa, Pinal, and Gila Counties.

1. Deposit in Black Mountains, T. 22 and 23 N., R. 19 and 20 W.

2. Deposit in sec. 2, T. 22 N., R. $20 \mathrm{~W}$.

3. Deposit southwest of Yucca in Black Mountains.

4. Deposit north of Haviland in Black Mountains.

5. Deposit in Chocolate Mountains.

6. Perlite Industries of Arizona plant at Phoenix.

7. Perlite Industries of Arizona mine at Superior.

8. E. E. Swift mine at Superior.

9. Chemi-Cote Perlite Co. mine at Superior.

10 . Casa Grande Perlite Co. deposit, south of Casa Grande.

11. Deposit north of Winkleman.

\section{Arkansas:}

Processing plant in Pulaski County.

1. Tennessee Products and Chemical Corp., 800 West Second, North Little Rock. 


\section{California:}

Deposits and processing plants in Modoc, Lassen, Sonoma, Napa, Solano, Contra Costa, Marin, Mono, Fresno, San Benito, Inyo, Kern, San Bernardino, Los Angeles, Riverside, and San Diego Counties.

1. Deposit in Warner Range, secs. 15, 22, T. 48 N., R. 15E., Mount Diablo meridian.

2. Deposit in northern part of Warner Range, in vicinity of Sugar Hill and Fandango Peak.

3. Evening Star deposit, NW $\frac{1}{4} N E \frac{1}{4}$ sec. 22, T. 46 N., R. 14 E., Mount Diablo meridian.

4. A. R. Close property, sec. 8, T. 39 N., R. 14 E. , Mount Diablo meridian.

5. Deposits exposed on west flank of Hot Springs Peak, 4 miles northeast of Wendel.

6. Large deposits occur on the south flank of Taylor Mountain, secs. 7, 8, T. 6 N., R. 7 W., Mount Diablo meridian.

7. Frazier property, sec. 1 and 11, T. 6 N., R. 6 W., Mount Diablo meridian.

8. Two deposits on Annadel Farms: (1) 3 miles northwest of Lawndale in a railroad cut, (2) in sec. 22, T. 7 N., R. 7 W. , Mount Diablo meridian.

9. Napa Perlite Co., Fred Holt ranch, near St. Helena, sec. 33, T. 8 N., R. 5 W., Mount Diablo meridian.

10. Perlite aggregates, Inc., $N \frac{1}{2}$ sec. 34, T. 8 N., R. 5 W., Mount Diablo meridian.

11. Deposits occur in secs. $32,33,34$ and 35, T. 8 N., R. 5 W., Mount Diablo meridian, 2 miles east of Rutherford railroad station.

12. Two occurrences on State Highway 29, about 5 miles east of Napa: (1) in roadcut. on edge of Basalt Rock Co., Mount George pumice deposit, (2) in roadcut about one-half mile east of first occurrence.

13. Deposit 2 miles southeast of Bismark Knob, sec. $28, T .6$ N., R. 5 W., Mount Diablo meridian.

14. Deposits occur along Green Creek, sec. 15, T. 5 N., R. 3 W., Mount Diablo meridian, about 5 miles north of Cordelia.

15. Perlite Aggregates, Inc., plant near St. Helena.

16. American Perlite Corp. plant at Richmond.

17. Perolite Products Co. plant at Sausalito.

18. Deposit northeast of Casa Diablo Hot Springs.

19. United States Mining Corp. deposit, secs. 19 and 30, T. 10 S., R. 34 E., Mount Diablo meridian, 7 miles south of Big Pine and 3 miles west of Fish Springs.

20. American Perlite Co. (Brooke) deposit, secs. 24 and 25, T. 10 S., R. 33 E., and secs. 29 and 30, T. 10 S., R. 34 E., Mount Diablo meridian, 7 miles south of Big Pine and $3 \frac{1}{2}$ miles west of Fish Springs.

21. Deposit at Pinnacles National Monument, along the Chalone Creek about three-quarters of a mile north of an abandoned Civilian Conservation Corps camp.

22. Perlite products plant, 93 Van Ness Avenue, Fresno.

23. Staats deposit, southern part of T. 18 S., R. 38 E., Mount Diablo meridian, about 13 miles south of Keeler.

24. Coso deposit, T. 21 and 22 S., R. 38 E., Mount Diablo meridian, about 7 miles northeast of Coso Junction and 2 miles west of Coso Hot Springs.

25. Southern Death Valley deposit, about 22 miles south of Furnace Creek Inn, and 4 miles southwest of Bennetts Well, Death Valley National Monument.

26. Sheephead Mountain deposit, western part of T. 21 N., R. 5 E., San Bernardino meridian, about 8 miles southwest of Shoshone on east flank of Sheephead Mountain.

27. Shoshone deposit, secs. 26 and 35, T. 22 N., R. 6 E., San Bernardino meridian, about 2 miles west of Shoshone on east side of Dublin Hills. 
28. Grey Eagle deposit in sec. 32, T. 28 S., R. 38 E., Mount Diablo meridian. The Black Eagle and Grey Eagle deposits comprise two 160-acre placer claims in the El Paso Mountains on the ridge north of Last Chance Canyon.

29. Black Eagle deposit in sec. 4, T. 29 S., R. 38 E., Mount Diablo meridian.

30. Deposits in sec. 27, T. 30 S., R. 36 E., Mount Diablo meridian, 8 miles north of Cantil in the El Paso Mountains.

31. Outcrops in many places in sec, 22, T. 31 S., R. 34 E., Mount Diablo meridian.

32. Deposits in low hills, a few miles north of Pilot Knob, T. 29 S., R, 44 E., Mount Diablo meridian.

33. Deposits in vicinity of Black Canyon, 18 miles south of Pilot Knob and 4 miles north of Coolgardie Camp, T. 31 S., R. 44 E., Mount Diablo meridian.

34. More-Lite Co, deposit near Ivanpah.

35. Deposit in Newberry Mountains, 6 miles south of Newberry.

36. California Perlite Corp. deposit, 6 miles north of Klondike and 12 miles north of Bagdad station on Santa Fe railway.

37. Deposit on southeast slope of Granite Mountains, sec. 10(?), T. 8 N., R. 13 E., San Bernardino meridian.

38. Deposit on Clipper Mountain about 18 miles northeast of Amboy.

39. Extensive deposits in Turtle Mountains, about 30 miles southwest of Needles.

40. NuLite Insulated Homes plant at Fontana.

41. Panacalite Pacific, Inc., plant, $825 \mathrm{E}$. 60th Street, Los Angeles.

42. Paramount Perlite Co. plant, 16236 South 11 inois Street, Paramount.

43. Peerless Perlite Co, plant, 2807 South Fairfax Avenue, Los Angeles.

44. McClure \& Erickson Corp. plant, 2416 Bedessen Avenue, Los Angeles.

45. United States Perlite Co. plant, 612 South Flower Street, Los Angeles.

46. Redco, Inc., plant, 11831 Vose Street, North Hollywood.

47. More-Lite Co. plant, Crestmore,

48. Extensive deposits at Little Chuckawalla Mountains, about 38 miles southwest of Blythe.

49. Harborlite Corp. plant, 696 Montgomery Freeway, Chula Vista.

\section{Cólorado:}

Deposits and processing plants in Denver, Chaffee, Gunnison, Fremont, Custer, Saguache, and Huerfano Counties.

1. Persolite Manufacturing Co. plant at Denver.

2. Nathrop deposit, secs. 11,12 , and 13, T. $15 \mathrm{~S} .$, R. $78 \mathrm{~W}$.

3. Morning Star deposit, sec. 35(?), T. 50 N., R. 5 E., near white-Pine, about $9 \frac{1}{2}$ miles from Sargents.

4. Deposit near headwaters of Tallahassee Creek.

5. Great Lakes Carbon Corp. (AleXite Engineering Division of Alexander Film Company) plant at Florence.

6. Rosita Hills deposit, secs. 32 and 33 , T. 22 S., R. 71 W, , and secs. 5 and 6, T. 23 S., R. $71 \mathrm{~W}$.

7. Prossers Rock deposit, secs. 6 and 7, T. 47 N., R. 3 E.

8. Cochetopa Dome deposit, sec. 36, T. 46 N., R. 2 E., about 24 miles from Darlin.

9. Cathedral deposit, SW $\frac{1}{4}$, T. 45 N., R. 1 W.

10. Polvo Blanco deposit, near Gardner.

District of Columbia:

Processing plant.

1. Atlantic Perlite Co., 1919 Kenilworth Avenue, N. E., Washington, D. C.

\section{Florida:}

Processing plants in Duval, Dade, and Indian River Counties.

1. Tennessee Products and Chemical Corp. at Jacksonville.

2. Airlite Processing Corp., Verno Beach.

3. Florida Perlite Company, 5137 N. E. Second Avenue, Miami. 


\section{Iilinois:}

Processing plants in Lake, Cook, Will, and Champaign Counties.

1. Lake Zurich Cement Products Co., Lake Zurich.

2. Silbrico Corp., 5901 West 66th Street, Chicago.

3. American Bildrok Co., 2001 West Pershing Road, Chicago.

4. F. E. Schundler and Co., Inc., 504 Railroad Street, Joliet.

5. Rholex Corp. of Mlinois, 310 East Bradley Street, Champaign.

\section{Indiana:}

Processing plants in Lake and Scott Counties.

1. United States Gypsum Co., East Chicago.

2. Airlite Processing Corp., Vienna.

\section{Lowa:}

Processing plants in Webster and Polk Counties.

1. United States Gypsum Co., Fort Dodge.

2. Midwest Perlite Products, Inc., 1120 Railroad Street, West Des Moines.

\section{Kansas:}

Processing plant in Wyandotte County.

1. Panacalite Perlite, Inc., Kansas City.

\section{Louisiana:}

Processing plants in Caddo and Orleans Counties.

1. R. S. Allday Clay Products, Inc., Shreveport.

2. Alatex Construction Service, 4516 D'Emencourt Street, New Orleans.

\section{Maryland:}

Processing plant in Baltimore County.

1. Perma-Rock Products, Inc., 19 West Franklin Street, Baltimore.

\section{Massachusetts:}

Processing plant in Suffolk County.

1. The Whittemore Co., 35 Harrison Street, Roslindale.

Michigan:

Processing plant in Kent County.

1. Gregg Products Co., 528 Bridge Street, Grand Rapids.

\section{Minnesota:}

Processing plants in Hennepin and Ramsey Counties.

1. Johnston Manufacturing Co., 2825 East Hennepin Avenue, Minneapolis.

2. Minnesota Perlite Corp., 315 West 86th Street, Minneapolis.

3. MacArthur Co., 936 Raymond Avenue, St. Paul.

\section{Missouri:}

Processing plant in St. Louis County.

1. Precast Slab and Tile Co., Inc., 1367 South Kingshighway Blvd., St. Louis.

\section{Nebraska:}

Processing plant in Douglas County.

1. Richlite Perlite Co., 2325 South 27th Street, Omaha.

\section{Nevada:}

Deposits and processing plants in Washoe, Pershing, Churchill, Nye, Lincoln, and Clark Counties.

1. United States Gypsum Co. plant at Empire.

2. Sno-Lite Products Co. plant at Reno.

3. United States Gypsum Co. deposit near Lovelock.

4. United States Gypsum Co. deposit near Fallon. 


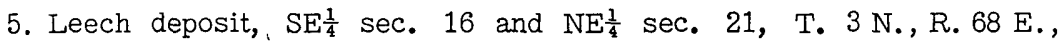
23 miles northeast of Pioche.

6. Hollinger deposit, secs. 3 and 10, T. 3 N., R. 68 E.

7. Free deposit, secs. 5 and 6, T. 2 N., R. 69 E., 14 miles northeast east of Pioche.

8. Combined Metals Reduction Co. deposit (Fairview), SW $\frac{1}{4}$ sec. 28, T. 4 N., R. $69 \mathrm{E}$.

9. Snow deposit, sec. 23, T. 1 N., R. 70 E., in Goodsprings mining district.

10. Grant deposit $4 \frac{1}{2}$ miles from Caliente.

11. Delamar Perlite Co. deposit near Caliente.

12. Eccles and Minto deposits, secs. 7, 8, and 17, T. 4 S., R. 63 E.

13. Acoma deposit, secs. 22 and 23, T. 5 S., R. 70 E., 6 miles south of Acoma.

14. Kopenite, Inc., deposit, approximately in T. 4 S., R. 63 E., 35 miles southwest of Caliente.

15. Robb deposit, about 14 miles southwest of Elgin.

16. Johnson and Fitchett deposit, secs. 33, 34, and 35, T. 8 S., R. 66 E., 13 miles northwest of Carp.

17. Boykin (Pulcepher) deposit, southeast of Acoma deposit, 7 to 8 miles from Union Pacific Railroad.

18. Deposit in Doughboy Group, 5 miles from Beatty.

19. Continental Engineering Service deposit near Las Vegas.

20. United States Perlite Manufacturing Co. deposit, about 20 miles south of Goodsprings and 12 miles from Roach Station on Union Pacific Railroad.

21. Nevada Panacalite, Inc., plant at Henderson.

22. Searchlight Insulation Products Co. plant at Searchlight.

23. Searchlight Insulation Products Co. mine, $S \frac{1}{2}$ sec. 9, and $N \frac{1}{2}$ sec. 16, T. $28 \mathrm{~S}$., R. $63 \mathrm{E}$.

24. NuLite Insulated Homes, Inc., mine, 12 miles west of Searchlight and 21 miles east of Ivanpah, Calif.

25. More-lite Co. deposit near Searchlight.

26. Basic Materials Co. deposit near Searchlight.

\section{New Jersey:}

Processing plants in Passaic and Middlesex Counties.

1. PerAleX of New Jersey, Inc., 64 Barclay Street, Paterson.

2. Coralux Perlite Corp. of New Jersey, Metuchen.

\section{New Mexico:}

Deposits and processing plants in Taos, Sandoval, Valencia, Socorro, Sierra, Grant, and Luna Counties.

1. Extensive deposit at No Agua Mountain, about 7 miles north of Tres Piedras.

2. Bland Canyon deposit.

3. Numerous deposits in Jemez Mountains.

4. Deposit in sec. 28, T. 17 N., R. 5 E., in Peralta Canyon.

5. Deposit in vicinity of Bear Springs, T. 17 N., R. 4 E.

6. Deposit about 8 miles northeast of Grants, at the eastern end of Grant Ridges.

7. Great Lakes Carbon Corp. plant near Socorro.

8. Great Lakes Carbon Corp. deposit about 3 miles southwest of Socorro.

9. Several deposits occur near and in secs. 14 and 23, T. 3 S., R. 4 W.

10. Deposit about 1 mile west of Lake Valley.

11. Pyramid Mountains deposit, about 8 miles south-southeast of Lordsburg.

12. McDonald ranch deposit, about $16 \frac{1}{2}$ miles by road northeast of Separ, in secs. 1, 2, 11, 12, T. 22 S., R. 15 W., and secs. 18, 19, 29, 30, 32, T. 22 S., R. 14 W.

13. Hermanas deposit about three-fourths of a mile north of Hermanas, a siding on the Southern Pacific Lines. 
New York:

Processing plants in Erie and Onondaga Counties.

1. Buffalo Perlite Corp., 100 Sugg Road, Buffalo.

2. Minerals Processing Corp., 520 Van Rensselear Street, Syracuse.

North Carolina:

Processing plant in Rowan County.

1. Carolina Perlite Co., Inc., Granite-Quarry.

\section{Ohio:}

Processing plants in Cuyahoga, Summit, and Hamilton Counties.

1. The Cleveland Gypsum Co., 1276 West 3d Street, Cleveland.

2. Geotic Industries, Inc., 765 Home Avenue, Akron.

3. Indoken Perlite Co., St. Bernard, Cincinnati.

\section{Oklahoma:}

Processing plants in Tulsa and Oklahoma Counties.

1. Ozark-Mahoning Co., Ozark Chemical Division, Tulsa.

2. Midwestern Perlite Corp., Oklahoma City.

\section{Oregon:}

Deposits in Wasco, Baker, Harney, Lake, and Malheur Counties.

1. Axford-Hunt deposit, northeast of Lady Frances mine, SW $\frac{1}{4} \mathrm{Sec}$. 16, extending into SE $\frac{1}{4} \mathrm{sec} .17, \mathrm{~T} .6 \mathrm{~S} ., \mathrm{R} .14 \mathrm{E}$.

2. Lady Frances mine, on Deschutes River, sec. 24, T.6S., R. 13 E.

3. Deposit at Dooley Mountains in southern Baker County.

4. Deposit at Juniper Ridge, southwest of Burns.

5. Deposit in Steens Mountains.

6. Deposit 10 miles south of Paisley on U. S. Highway 395 to Lakeview.

7. Deposit in Cedar Mountains near Owyhee.

8. Northwest Perlite Corp., 9 miles north of Jordan Valley.

\section{Pennsylvania:}

Processing plants in Lehigh, Allegheny, and Delaware Counties.

1. Pennsylvania Perlite Corp., Schoenersville.

2. Panacalite Perlite Co., 340 North Braddock Avenue, Pittsburgh.

3. Perlite Manufacturing Co., Carnegie.

4. Perlite Products Co., Inc., Primos.

\section{Tennessee:}

Processing plant in Davidson County:

1. Tennessee Products and Chemical Corp., Nashville.

\section{Texas:}

Deposits and processing plants in Tarrant, Dallas, Nolan, Midland, and Hudspeth Counties.

1. Texas Perlite Corp. plant, 2611 North Sylvania Street, Fort Worth.

2. Texas Panacalite Co. plant, 117 North Britain Road, Irving.

3. United States Gypsum Co. plant at Sweetwater.

4. Perlite Industries, Inc., plant at Terminal.

5. Perlite of Houston, Inc., plant, Houston.

6. Small deposits of perlite near Eagle Spring and Panther Bluff.

Utah:

Deposits and processing plants in Salt Lake, Tooele, Millard, Beaver, and Washington Counties.

1. Utco Products Co. plant at Salt Lake City.

2. Combined Metals Reduction Co. plant at Bauer.

3. Roy A. Day \& Associates deposit, $2 \frac{1}{2}$ miles from Bloom.

4. Huntsman deposit, T. 23 S., R. 8 and 9 W., about $3 \frac{1}{2}$ miles east of Union Pacific Railroad main line between stations of Cruz and Bloom Siding, and 23 miles west of Kanosh. 
5. Christensen Construction Co. deposit near Pumice.

6. Utah Pumice and Perlite, Inc., deposit 30 miles north of Milford,

7. Utco Products Co. deposit, T. 27 N., R, 9 W., about 14 miles northeast of Milford.

8. Perlite, Inc., deposit near Milford.

9. Perlite. Inc. plant near Milford.

10. LeRoy A. Wilson deposit, 9 miles from Crestline, Nev.

\section{Virginia:}

Processing plant in Hopewell County.

1. Virginia Perlite Corp., Hopewell.

\section{Washington:}

Deposits in Chelan, Klickitat, King, and Pierce Counties.

1. White River area.

2. Wenatchee area,

3. Satus Creek deposit.

\section{Wisconsin:}

Processing plants in Outagamie and Milwaukee Counties.

1. Midwest Perlite Co., 912 West College Avenue, Appleton.

2. Badger Perlite Co., 3101 West Mill Road, Milwaukee.

\section{Wyoming:}

Deposit in Yellowstone National Park.

1. East side of the Firehole River, opposite Excelsior Geyser and the Midway Geyser bașin.

\section{LITERATURE CITED}

Allen, J. E., 1946, Perlite deposits near the Deschutes River, southern Wasco County, Oregon: Oreg. Geol. and Min. Industry Short Paper 16, 17 p.

1947. Another perlite deposit in Oregon: Ore Bin, v. 9, no. 8, p. $59=66$. Atlantic Perlite Company, no date, Character and properties of perlite fines, 5 p., Washington, D. C.

Barberii, E. E., 1949, Perlite used as mud-additive material proves highly effective in tests in combating lost circulation: Oil and Gas Jour., v. 48, no. 12, p. $280,283-284$.

Burbank, W. S., Lovering, T. S., Goddard, E. N, , and Eckel, E, B, 1.935, Geologic map of Colorado: U. S. Geol. Survey.

Bush, A. L., 1951, Sources of lightweight aggregates in Colorado: Colo. Sci. Soc. Proc., v. 15, no. 8, p. 303-368,

Calif. Div. Mines Min, Inf. Service, 1948, Notes on current mining activity in California: $v, 1$, no, $3,9 \mathrm{p}$.

1951, Mining and industrial news notes: v. 4, no. 4, 8 p.

1953, Discovery of perlite in San Benito County: v. 6, no. 6, 9 p.

Campbell, M. R. , Emery, W. B., Heald, K, C., and others, 1925, Geologic map of Wyoming: U. S. Geol. Survey,

Chem. and Metall. Eng., 1945, v. 52, July, p. 140, 142, 170, 172.

Chesterman, C. W., 1950a, Perlite deposits in Sonoma County: Calif. Jour. Mines and Geology, v. 46, no. 1, p. 81-82.

$1950 \mathrm{~b}$, Pumice, pumicite, and perlite: Calif. Div. Mines Bull. 156, p. 199-203.

Cochran, K. I., 1951, Perlite resources, Meadow Valley Wash area, Clark and Lincoln Counties, Nev.; Beaver and Millard Counties, Utah, Union Pacific Railroad Co., 24 p.

Darton, N. H., 1928, Geologic map of New Mexico: U. S. Geol. Survey.

Darton, N. H., Lausen, Carl, and Wilson, E. D., 1924, Geologic map of Arizona: Ariz. Bur. Mines.

Davis, F. F., 1948, Mines and mineral resources of Napa County, Calif.: Calif. Jour. Mines and Geology, v. 44, no. 2, p. 159-188. 
Diller, J. S., 1897 (revised), Description of the Roseburgquadrangle, Oreg.: U. S. Geol. Survey Geol. Atlas, folio 49. [1898]

1898, The educational series of rock specimens: U. S. Geol. Survey Bull. 150.

Eng. and Min. Jour., 1950, v. 151, no. 5, p. 128.

Gillerman, Elliot, 1953, Fluorspar deposits of the Eagle Mountains Trans-Pecos Texas: U. S. Geol. Survey Bull. 987.

Goranson, R. W., 1931, The solubility of water in granite magmas: Am. Jour. Sci., ser. 5, v. 22, p. 481-502.

Gustafson, F. D., 1949, The mining, milling, and processing of perlite: Am. Inst. Min. Met. Eng. Trans., v. 184, p. 313-316.

Hague, Arnold, 1892, Geology of the Eureka district, Nevada: U. S. Geol. Survey Mon. 20.

Hewett, D. F., 1931, Geology and ore deposits of the Goodsprings quadrangle, Nev.: U. S. Geol. Survey Prof. Paper 162, geol. map.

Huntting, M. T., 1949, Perlite and other volcanic glass occurrences in Washington: Wash. Div. Mines and Geology Rept. Inv. 17, $77 \mathrm{p}$.

Johannsen, Albert, 1932, A descriptive petrography of the igneous rocks, Univ. Chicago Press, v. 2, 428 p.

Lenhart, W. S., 1950, Processing perlite ore for controlled expansion: Rock Products, v. 53, no. 10 , p. 98-100.

Mason, R. S., 1951, Lightweight aggregate industry in Oregon: Oreg. Geol. and Min. Industry Short Paper 21, p. 13-15.

Min. World, 1948, v. 10, no. 7, p. 64. 1949 , v. 11 , no. 10 , p. 80.

1950 , Permalite-rock to plaster, v. 12 , no. 11 , p. 28-31.

1954 , U. S. metal and mineral markets, v. 16, no. 7, p. 86.

Murdock, J. B., and Stein, H. A., 1950, Comparative furnace designs for the expansion of perlite: Min: Eng., v. 187, no. 1, p. 111-116.

Norman, L. A., Jr., and Stewart, R. M., 1951, Mines and mineral resources of Inyo County: Calif. Jour. Mines and Geology, v. 47, no. 1, 137 p.

O'Brien, J. C., 1948, Current and recent mining activities in the Redding district: Calif. Jour. Mines and Geology, v. 44, p. 335-378.

Oregon State map showing mineral deposits, 1947, U. S. Geol. Survey Cons. Div. Min. Class Branch.

Perlite Institute, 1950, Fireproofing with perlite: 4 ed., 6 p.

Perlite Torch, 1951, v. 1, no. 2; 4 p. 1952 , v. 2, no. 1, 4 p.

Pit and Quarry, 1949, Schundler and Company processing Nevada perlite at Joliet, Il., v. 41 , no. 12 , p. 57.

p. 66 .

1951, New perlite plant to tap rich 5,000,000-ton deposit, v. 43, no. 9 , 1953, New Mexico perlite deposit opened by Texas concern, v. 45, no, 7, p. 162.

Ralston, O. C., 1946, Perlite, source of synthetic pumice: U. S. Bur. Mines Inf. Circ. $7364,11 \mathrm{p}$.

Ransome, F. L., 1898, Some lava flows of the western slope of the Sierra Nevada, Calif.: Am. Sci. Jour., v. 5, ser. 4, p. 355-375.

Ross, C. P., and Forrester, J. D., 1947, Geologic map of Idaho: U. S. Geol. Survey.

Smith, J. P., 1916, Geological map of California: Calif. Min. Bur.

Taylor, C. W., 1950, Perlite popping from a shaky start, a solid new industry: Chem. Eng., v. 57, no. 1, p. 90-94.

Tucker, W. B., and Sampson, R. J., 1943,Los Angeles field district-mineral resources of San Bernardino County: Calif. Jour. Mines and Geology, v. 39, no. $4,549 \mathrm{p}$.

Tucker, W. B., Sampson, R. J., and Oakeshott, G. B., 1949, Mineral resources of Kern County: Calif. Jour. Mines and Geology, v. 45, no. ¿, p. 203-297.

Utley, H. F., 1951, "Retired" Californian operates 2,000-bag-per-day perlite plant: Pit and-Quarry, ข. 43, no. 10, p. 76-77, 100. 
Valentine, G. M. , 1949, Inventory of Washington minerals-pt. 1, nonmetallic minerals: Wash Div. Mines and Geology, Bull. 37, p. 67.

Washington preliminary geologic map, 1936, Wash. Dept. Cons. and Devel.

Washington, H. S., 1917, Chemical analyses of igneous rocks published from 1884 to 1913, inclusive, with a critical discussion of the character and use of analyses: U. S. Geol. Survey Prof. Paper 99.

Wells, R. C., 1937, Analyses of rocks and minerals: U. S. Geol. Survey Bull. 878, p. 34-35.

Westgate, L. G., and Knopf, Adolph, 1932, Geology and ore deposits of the Pioche district, Nevada: U. S. Geol. Survey Prof. Paper 171, geol. map.

Wilfey, R. D., and Taylor, C. W., 1950, Perlite mining and processing-a new industry for the West: Eng. and Min. Jour., v. 151, no. 6, p. 80-83.

Wilpolt, R. H., and Wanek, A. A., 1951, Geology of the region from Socorro and San Antonio east to Chupadrea Mesa, Socorro County, N. Mex.: Oil and Gas Inv. Map OM 121.

Wilson, E. D., and Roseveare, G. H., 1945, Arizona perlite: Ariz. Bur. Mines Circ. $12,10 \mathrm{p}$.

Wood, J. A., 1948, Occurrences and processing of perlite: N. Mex. Miner and Prospector, v. 10, no. 4, p. 11-12. 


\begin{tabular}{|c|c|}
\hline Abstract $\quad \begin{array}{l}\text { Page } \\
375\end{array}$ & Occurrence-Continued \\
\hline Acknowledgments & 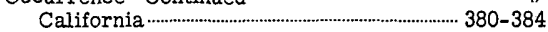 \\
\hline Data, source of & Colorado \\
\hline Definition of periite. 376 & Nevada \\
\hline Economic aspects & 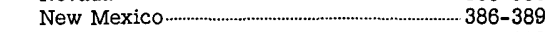 \\
\hline Geology & Oregon \\
\hline Glasses, volcanic, characteristics ……........... 378, 379 & Texas .................... \\
\hline chemical analyses & Utah \\
\hline devitrification & Washington... \\
\hline History & Wyoming \\
\hline Introduction & Origin \\
\hline Literature cited & perlite Institute.... \\
\hline Milling & 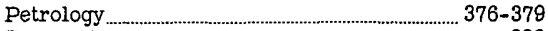 \\
\hline 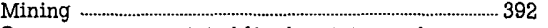 & 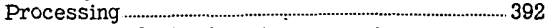 \\
\hline $\begin{array}{l}\text { Occurrence, annotated list by states and } \\
\text { counties }\end{array}$ & $\begin{array}{l}\text { Processing plants, locations according to } \\
\text { states }\end{array}$ \\
\hline & \\
\hline
\end{tabular}

